\title{
Cross-Country Evidence on the Link between the Level of Infrastructure and Capital Inflows*
}

\author{
Mathias Hoffmann \\ Department of Economics, Trinity College Dublin ${ }^{\dagger}$
}

14th June 2002

\begin{abstract}
A bstract
This paper empirically investigates the relationship between public infrastructure and international capital flows. Out of a sample of thirty countries a cross-sectional econometric model is constructed to estimate the effects. Various components of infrastructure variables are tested in relation to their impact on different kinds of external capital liabilities. The results suggest a positive relationship between the level of infrastructure and capital inflows. However, statistical significance cannot be established for all variables in question.
\end{abstract}

JEL Classification: C21, F21, F30, F41.

Keywords: Long-Term Capital Movements, International Finance and Open Economy Macroeconomics.

\footnotetext{
${ }^{*}$ A version of this paper is forthcoming in the Journal 'Applied Economics'. I am grateful to Philip Lane and thank participants at the Trinity International Group Seminar for helpful comments and suggestions. This work is part of a research network on 'The Analysis of International Capital Markets: Understanding Europe's Role in the Global Economy', funded by the European Commission under the Research Training Network Programme (Contract No. HPRN-CT-1999-00067).

${ }^{\dagger}$ Address of Correspondence: Mathias Hoffmann, Department of Economics, Trinity College, Dublin 2, Ireland. email: hoffmanm@tcd.ie
} 


\section{Introduction}

The aim of this paper is to shed further light on the determinants of capital inflows to developing countries. In particular, the relationship between the level of infrastructure in these countries and their ability to attract external capital is investigated. The rationale of this paper becomes evident when examining the literature on the provision of public capital and productivity. Public investment can generate important positive spillover effects for private sector investment. ${ }^{1}$ Aschauer (1989) analyses the relationship between public capital and production, using aggregated data of the United States. His results point out that the United States' productivity decline of the 1970s was due to under investment in infrastructure. By contrast, one could argue that public capital is endogenous so that the causation runs from productivity to public investment (Fernald (1999)). The author explores that the aggregate correlation between productivity and public capital in the U.S. primarily reflects the causation from public capital to productivity. Fernald considers roads and his evidence suggests that the massive road building during the 1960s offered a one-time increase in the level of productivity. Demetriades and Mamuneas (2000) create an intertemporal model of output and employment to test for the effects of public infrastructure capital and their rates of return. They confirm Aschauer's finding for twelve OECD countries in the long-run. The authors argue that the productivity of public capital is significantly lower than the one of private capital in the short-run but more productive in most countries analysed in the long-run. Their findings suggest that the short-run rates of return to public capital are rather low while the long-run rates of return tend to be relatively high. Hence, public capital is often oversupplied in the short-run and undersupplied in the long-run. They conclude that it is important to consider the effects of public capital not only on current but also on future producer decisions. In the context of international capital, Clarida (1993) looks at the relationship among international capital flows, public investment and growth. He develops a neoclassical growth model under perfect international capital mobility in which private and public capital are complements in production. Empirically he finds out that productivity and public capital are cointegrated in four OECD Countries. ${ }^{2}$ Nevertheless, the question whether productivity is exogenous or endogenous with respect to public capital cannot be answered so that the structural relationship needs to be investigated further.

This paper attempts to explain the structural relationship between the initial public infrastructure conditions of countries and capital movements in a cross-section of countries. It concentrates on different types of capital stocks and flows, namely total liabilities, portfolio eq-

\footnotetext{
${ }^{1}$ For an overview on this literature see Gramlich (1994).

${ }^{2}$ Namely the USA, Germany, France and the United Kingdom.
} 
uity, FDI and debt. The relation between the stock of a country's infrastructure and the inflow of external capital will be conditional on a set of country-specific characteristics. Airports, power plants, railways, roads or telecommunication facilities are important components of national production. Hence, the paper focuses on the provision of infrastructure and it will be found out whether it influences international investors' decisions to invest in particular countries.

The following section provides the motivation for the data choice and explains the relationship to be addressed. The empirical part presents the descriptive statistics of the data in section 3.1, while the econometric approach will be explained in part 3.2. The results of the cross-sectional analysis and the empirical evidence of capital flows and its relation to the level of infrastructure will be discussed in section 3.3. Section 4 concludes.

\section{Choice of Variables}

Capital market frictions and country specific economic conditions play an important role in influencing investment decisions internationally. Specific infrastructure provision may affect market distortions and domestic performance by reducing information collection costs, transporting costs or capital formation costs.

A country's telecommunication system has an important impact on information collection and transmission. It can promote a fast exchange of information and thereby increase the ability of investors to acquire important knowledge about recent changes in the investment environment. Hence, investors are able to monitor investment projects more closely. Obviously, geographical distance is relevant. The greater the distance, the less attractive a country is for investment, due to increasing costs of acquiring information. Information costs are expected to be positively correlated to distance. The provision of a well-established telecommunication network lowers the costs of collecting information. Therefore, international telephone circuits are used as a variable which captures the informational dimension in the empirical section. The collection of personal information is another important factor in deciding whether to invest in a country, so that good air connections are potentially important. By using the explicit variable of flight air-departures, this effect will be measured.

Transportation costs also have an impact on investment decisions. They influence the relative prices of capital goods, since some goods must be transported from one region to another to start or continue the production process. A good network of transportational infrastructure can lower the costs of moving goods between regions and thereby increases the efficiency of the production process in the country. The better the transport system, the lower the costs. This relationship is measured by using the total length of paved roads as a proxy for the transportation system. The 
assumption is that there should exist a positive correlation between the length of roads in the country and the propensity to invest in such a country. The costs of sending goods to retailers and distributors at home and abroad are decreasing with a rising level of transport facilities. It is interesting to consider countries which are landlocked, i.e. they have no direct access to coastal areas, hence, they might possibly have higher costs of final production. ${ }^{3}$ Landlocked countries can therefore be expected to receive less inflows of new investment. Nevertheless, the provision of an alternative network in terms of air-transport could attract more investment into these regions. The above mentioned variable on air-departures might also be able to capture those effects.

Another aspect worthwhile investigating is the question whether the geographical position of the country has any impact on capital flows. In general one can argue that countries with an increasing distance to the equator are equipped with a better infrastructure and are stronger in the process of production and economic growth. Looking at Africa, most countries at the equator do not have a solid infrastructure basis yet and lack a good economic performance. Countries closer to the equator are expected to receive smaller amounts of capital inflows, especially portfolio flows. To assess this latitude is utilised.

Countries which tend to be more diversified in production are less affected by the strong fluctuations of commodity prices. Hence, they may represent better credit risks. To consider the product differentiation in exports the ratio of mineral exports relative to merchandise exports is used to test for such effects.

In order to account for macroeconomic heterogeneity of countries additional control variables are introduced. The country size (here the total GDP ) plays an important role. On the one hand large countries are more attractive due to the existence of fixed costs in acquiring information about the investment conditions in the country. They may also be less vulnerable to external shocks, due to diversified production. On the other hand, a small open country can be more attractive since its economy may be able to adjust to changes in the international economic environment more quickly and flexibly. This makes such countries more competitive and safe to invest in. The wealth of the country, GDP per capita, has implications for the countries' positions as a net creditor or debtor. Wealthier countries tend to have more asset positions than liabilities. ${ }^{4}$ The openness of a country should not be neglected as more open countries represent better credit risks. They are more vulnerable to external sanctions and gain less from defaulting. Openness is measured by using the sum of predicted bilateral trade shares from the geographical

\footnotetext{
${ }^{3}$ Especially developing countries need to import most equipment-investment from abroad to start the production.

${ }^{4}$ This argument has been confirmed by Lane and Milesi-Ferretti (2001a).
} 
determinants in the gravity theory (see Frankel and Romer ,1999).

\section{Evidence on the Linkage of Infrastructure and Capital Flows}

In this section a cross-country data set, exhibited in Tables 1 and 2 , is utilised to test the prediction that the inflows of external capital to countries are positively related to the level of infrastructure in the economy. ${ }^{5}$ The relationship becomes vital if the level of infrastructure is able to promote the inflow of capital to a certain extent.

The regression analysis makes use of a cross-sectional approach. This type of approach allows to abstract oneself from short-run fluctuations in the external capital liabilities which occur due to temporary shocks in the world capital markets. Another motivation for a cross-sectional analysis is that measures of infrastructure are more convincing in capturing cross-country variations rather than tracking changes in the level of infrastructure of an individual country over time.

The cross sectional analysis consists of 30 countries from Asia, Africa as well as Latin America and uses data from 1990 to 1995 (refer to Table 3). ${ }^{6}$ With reference to the stock of total liabilities and debt the sample size is restricted to 29 observations due to the fact that South Africa did not report on these items. The results on longer time series, including periods from the 1970s onwards, were similar to the ones reported here. A sample which also containing industrialised countries was also experimented with. However, the most interesting results occurred for the developing country sample.

The developing country sample appears to be appropriate since variations in infrastructure between developing countries may have a stronger impact on the attraction of capital inflows. The definition of developing countries in this paper is broadly consistent with those countries likely to be elected for developing country treatment by the World Trade Organization (WTO). The group therefore includes the Republic of Korea and Singapore, which were clearly developing economies in the last decades but are now classified by the World Bank as high-income. However, Singapore is not included in the list of developing countries. ${ }^{7}$ Since Singapore has an

\footnotetext{
${ }^{5}$ In an earlier version of this paper public investment and its relationship with external capital inflows was also considered. The measurement was obtained by the construction of a perpetual public capital stock. However, since one cannot say whether public investment is used efficiently, those results are not reported.

${ }^{6}$ Multivariate outliers were tested for using the procedure suggested by Hadi $(1992,1994)$ in the regression specification.

${ }^{7}$ In general an outlier like Singapore is not necessarily bad. The variation in the data is exactly what allows the identification of relationships. However, if an outlier is non-representative due to factors that make it different from the rest of the sample, it makes sense to exclude it from the sample.
} 
extraordinary position as an financial centre, this country was excluded from the estimation. Including Singapore improves the results in fact.

\subsection{Descriptive Statistics}

This section discusses the sample's descriptive statistics. Figures 1 to 3 are histograms of the infrastructure variables used in the empirical section. Each histogram is divided into four groups. Figure 1 shows air-departures per inhabitants at 1990. Group 1 contains the 16 countries (53 percentage of the sample size) with a level of less than 0.2 air-departures in 1990. Only two countries have a ratio of 0.6 air-departures per capita or above. Figure 2 displays paved road length. Whereby 16 countries are grouped in category 1, which represents paved roads per square $\mathrm{km}$ below $0.05 \mathrm{~km}$. Six countries belong to group 2 with a road length below $0.1 \mathrm{~km}$ per square $\mathrm{km}$. Only 27 percent of the countries provide a paved road length of more than $0.1 \mathrm{~km}$ per square $\mathrm{km}$. Figure 3 presents the ratio of international telephone circuits per inhabitant. Group 1 contains 19 countries (67 percent of the sample size), which dispose of an international telephone circuits ratio of less than 0.09. Group 3 and 4 consist of only three countries, which have more than 0.17 international telephone circuits per capita. Accordingly, Figures 1 to 3 indicate considerable cross-country heterogeneity in the infrastructure variables. Table 4 reports the summary statistics of all variables included in the regression analysis. as evidenced above, there is a considerable standard deviation in the data on the level of infrastructure. The analysis of the capital data reveals that the mean of all stock and flow positions is positive for all countries in the sample.

\subsection{Econometric A pproach}

For the estimation procedure ordinary least squares (OLS) is applied to specify the prediction that there exists a link between the level of infrastructure and capital flows to a country. ${ }^{8}$ The standard errors are corrected by the White procedure to adjust for the presence of heteroscedasticity in the data. Overall, two concepts of external capital liabilities, namely gross liability flows and stocks, are considered. Much of the benefits of asset trade arise from gross rather than net positions. Results for net asset positions were also tested. Since most of the countries included in this sample are net debtors, the relationship found is not very different to the one reported for the gross liability data.

\footnotetext{
${ }^{8} \mathrm{An}$ infrastructure index was also experimented with. The index was constructed out of a principal component analysis. The first and second principal component were utilised to construct weights of the infrastructure variables. However, the index did not significantly enter the regression analysis.
} 
The stock position is the relevant state variable on the macroeconomic level. Flows arise to close the gap between the actual and desired stock position. Financial flows and stocks can be divided into FDI, portfolio equity and debt. Thus, to get a precise picture, the stock and flow variables are split into their sub-components. All liability measures are calculated as a share of GDP and then used as a dependent variable $y_{\mathrm{i}}$ in the regression analysis. This ratio therefore expresses the stocks or flows relative to GDP. The variable $y_{\mathrm{i}}$ is calculated as an average over the period 1990-95.

For the OLS application, the level of infrastructure in the countries is captured by $x_{\mathrm{i}, \text { level for }}$ each infrastructure variable separately and jointly by the vector $X_{\mathrm{i}, \text { level }} \cdot{ }^{9}$ The latter provides the set of infrastructure variables explained above: air-departures, roads as well as international telephone circuits. Air-departures and telephone circuits are expressed in per capita terms while roads are calculated as a ratio to square $\mathrm{km}$ of the countries. Since the time period 1990-95 is observed, the level of infrastructure relates to the stock of infrastructure in 1990 .

In the first step, $y_{\mathrm{i}}$ and $x_{\mathrm{i} \text {,level }}$ are regressed in a bivariate form. Subsequently, a set of other variables $Z_{\mathrm{i}}$ is added. $Z_{\mathrm{i}}$ includes regressors such as natural resources, latitude and trade openness, which could also be potential determinants for capital inflows to countries. $Z_{\mathrm{i}}$ also includes variables which control for heterogeneity between the cross section of countries. Country differences are adjusted by using measures of country size (GDP) and wealth (GDP per capita). These two variables are in logs. Accordingly, the basic specification of the regression analysis can be expressed as follows:

$$
y_{\mathrm{i}}=\alpha+\beta x_{\mathrm{i}, \text { level }}+\gamma^{0} Z_{\mathrm{i}}+u_{\mathrm{i}}
$$

In the last step we use the complete set of infrastructure variables $X_{\mathrm{i}, \text { level }}$ is utilised. Additionally, a set of dummy variables, $d_{\mathrm{i}}$, is used in order to account for unobservable factors such as being landlocked. As a result, the estimated model then takes the form:

$$
y_{\mathrm{i}}=\alpha+\beta^{0} X_{\mathrm{i}, \text { level }}+\gamma^{0} Z_{\mathrm{i}}+\delta d_{\mathrm{i}}+u_{\mathrm{i}}
$$

\footnotetext{
${ }^{9}$ In previous drafts effects of other infrastructure variables, such as railway length, energy generating power, number of telephones and telephone mainlines as well as air transport (airfreight and persons carried) were tested for. The last two can be seen as substitutes for international telephone circuits and air-departures. The results obtained were similar to the ones we report here. The former variables were not included due to the fact that they did not add any further explanatory power to the model. To measure the effect of human capital on the attraction of capital inflows a variable, which is calculated by the percentage of secondary schooling degrees in the work force, was defined. This variable was not statistically significant.
} 


\subsection{Results}

Following the procedure introduced above the results are discussed in the following subsections. Regression results for the cross-section analysis on capital stocks are presented in Tables 5 to 7 whereas Table 8 exhibits capital flow data. Since the focal point of interest lies in comparing the influence of the same set of determinants across categories, the same set of specification as explained below for Table 5 is adopted in each case.

\subsubsection{0-95 Cross-Section A nalysis of the Stock Data}

For the analysis of the stock of total liabilities, 29 countries are included in the sample as South Africa is excluded due to missing observations. Table 5 contains the regression results of the total liability stock relative to GDP as the dependent variable. In columns (1) to (3) the basic bivariate relationship between the average total liability stocks and the infrastructure variables are shown. A positive effect for measures on the level of roads, air-departures as well as the level of international telephone circuits is established. However, only air-departures and telephone circuits enter significantly into the basic specification. Those variables are able to explain 20 and 42 percent of the cross-country variations in total liabilities respectively. A one percentage point improvement in the level of air-departures in 1990 is associated with an increase in the stock of total liabilities of 0.802 percentage points. The effect is even stronger for international telephone circuits. Here, a one percentage point improvement in the level of international telephone circuits in 1990 leads to a rise in total liabilities by 2.982 percentage points. To allow for the crosssectional variations in size and wealth, GDP and GDP per capita are included as general control variables in the regressions in columns (4) to (10). The other regressors are jointly added in columns (7) to (10). When controlling for wealth and size of the countries in columns (4) to (6), only international telephone circuits maintain a positive and individually significant relationship with the average total liability stock. Interestingly, throughout columns (4) to (6), total GDP enters negatively and is statistically significant in the specification. Thus, smaller countries hold more liabilities relative to GDP. Columns (7) to (9) include all explanatory variables for each of the infrastructure variables. Again, only international telephone circuits reveal a significantly positive relationship with the total liability stock. The size of the country loses significance as the remaining explanatory variables are added. Instead, trade openness now enters significantly and its point estimate is positive and stable across columns (7) to (9). One explanation is that trading countries represent a better credit risk and receive more liabilities. On average, a ten percentage point increase in trade openness is associated with an 0.15 percentage point increase in total liabilities. Latitude enters the specification individually significantly and negatively 
in columns (8) and (9). This implies that the geographical position matters. Countries with increasing distance to the equator hold a lower stock of total liabilities. Column (10) in Table 5 includes all infrastructure variables and the other explanatory variables. 67 percent of the cross-sectional variation in total liabilities is explained by the last regression equation. None of the infrastructure variables is individually significant. Joint significance of the infrastructure variables is tested for using a F-Statistic. ${ }^{10}$ The joint test for the three variables has a p-value of 0.239 . Thus, the infrastructure variables are jointly insignificant. Only trade openness keeps its statistical significance and enters with a positive sign. The other regressors have much less importance in the final specification.

The analysis of the relationship between the average stock of FDI liabilities and the level of infrastructure is illustrated in Table $6 .^{11}$ The sample size consists of 30 countries. The specification for the columns (1) to (10) is identical to the one explained above. In the bivariate analysis air-departures enter significantly although roads and international telephone circuits also have a positive sign. A three percentage point increase in the level of air-departures as a ratio to total population is associated with a 1 percentage point increase in the FDI stock of a country. Overall, 48 percent of the variation in FDI is explained in the cross-section. Air-departures remain individually significant when further controls are added and its positive point estimate remains stable across columns (4), (7) and (10). Controlling for wealth and size in columns (4) to (6) leaves the other infrastructure variables unchanged. GDP enters with a negative sign that is only marginally significant in the specification for roads and international telephone circuits in columns (5) and (6). Throughout columns (7) to (9) country size, trade openness and natural resources have a strong negative and individually significant impact on the average stock of FDI liabilities. This impact is stable for each of the infrastructure variables used. The implication is that, other things being equal, less open countries have a higher stock of FDI liabilities. Countries that are equipped with higher amounts of natural resources relative to merchandise exports have less FDI liabilities. This emphasises, leaving other controls unchanged, that countries with a diversified export structure are better candidates for receiving FDI. The dummy concerning being landlocked has a negative and highly statistically significant sign throughout columns (7) to (10). Landlocked countries receive less FDI investment, which implies that countries with ports and harbours provide better opportunities for FDI. Column (10) shows the joint impact of the infrastructure variables. Again, 67 percent of the variation in the cross-section is

\footnotetext{
${ }^{10}$ Since a linear restriction in a small sample is tested for the F statistic instead of the chi-square distribution is utilised.

${ }^{11}$ One can assume that parts of the FDI inflows in the 1990 s are due to privatisation. The relationship between the adopted privatisation schemes in many of the countries and FDI stocks and flows were analysed. However, a significant relationship for the countries could not be found.
} 
explained by the regression specification. Interestingly, looking at latitude, countries with greater distance to the equator receive more FDI. While air-departures remain significantly positive in the regression, a negative and individually significant impact of roads and international telephone circuits can be observed. A test for the joint significance of the three infrastructure variables has a p-value of 0.000; therefore the variables are also jointly highly significant. The arising question is why roads and international telephone circuits become negative in sign. One explanation is that the correlations between the infrastructure variables, especially between air-departures and international telephone circuits, contribute to the changes in sign. The findings in Table 6 suggest that the level of air-departures is an important determinant of stock of FDI in a crosssection of countries. As before, openness is important for explaining the stock of international capital. This time openness is negatively correlated to FDI. The results obtained suggest that also natural resources have a negative impact on the attraction of FDI stocks. An interesting finding, illustrated in Table 6, is that countries with access to coastal areas, i.e. ports, are able to attract more FDI liabilities. The analysis of the portfolio equity stock does show no effects overall. Therefore, results are omitted from the discussion.

The relationship between the average stock of debt and infrastructure is documented in Table $7 .^{12}$ Out of the three bivariate specifications in columns (1) to (3) the variable on international telephone circuits is significant at the one percent level and explains 30 percent of the variation in the stock of debt across countries. A one percentage point improvement in the level of international telephone circuits is associated with an increase of 2.35 percentage points in the stock of debt. Controlling for cross-sectional variations in wealth and size in columns (4) to (6), even international telephone circuits lose their statistical significance. In all three columns the size variable, GDP, has a negative and individually highly significant impact on the average stock of debt. Introducing the remaining regressors in columns (7) to (9) does not alter the characteristics of the infrastructure variables. None of the infrastructure variables enters significantly in our specification, even though they keep their positive sign. However, now also the wealth of the country plays a negative and individually significant role in determining the average stock of debt. This suggests that poorer countries hold higher stocks of debt. As it is the case for the stock of total liabilities, openness is positively related to the countries' stock of debt liabilities. This is confirmed in columns (7) to (10). Natural resources enter marginally significantly in the specification for roads and international telephone circuits and with a negative sign for the three infrastructure variables. The joint specification in column (10) reveals the importance of the geographical position of countries. Countries closer to the equator receive more debt. A joint test provides a p-value of only 0.924 , implying no joint significance of the infrastructure variables

\footnotetext{
${ }^{12}$ South Africa is excluded due to missing observations.
} 
exists. Only trade openness enters individually significantly.

The findings for the average stock of foreign capital liabilities and its sub-components can be summarised as follows. Considering the infrastructure variables separately, roads do not seem to contribute to the attraction of new international capital. By contrast air-departures and international telephone circuits have a positive and statistically significant relationship with the average total liability stock for the period 1990-95. Air-departures also show a positive and statistically significant influence on FDI, while international telephone circuits have a positive impact on the attraction of new debt. Overall, the joint impact of the chosen infrastructure variables on the stock of capital inflows is not statistically significant. An exception is provided by the sub-component on FDI. Here a statistical significant impact of infrastructure on new FDI is found.

\subsubsection{0-95 Cross-Section A nalysis of the Flow Data}

The analysis of the average capital flows illuminates interesting effects on FDI flows. All infrastructure variables enter with a positive sign into the bivariate specification of FDI flows in Table 8. However, as seen above for the stock of FDI, only air-departures are statistically significant at the one percent level (column (1)). A 2.5 percentage point increase in the level of air-departures raises the average inflow of FDI liabilities by 0.1 percentage point. Note that 33 percent of the cross-country variations in FDI flows are explained by this variable. The result remains valid when country differences, depicted in columns (4) to (6), are controlled for. However, the inclusion of the remaining regressors in columns (7) to (9) wipes out the individual significance of the air-departure variable and leaves the other infrastructure variables unchanged. In all three specifications of columns (7) to (9) trade openness has a negative and statistically significant impact on the specifications. The same is true for natural resources in columns (8) and (9). In these columns the dummy variable concerning being landlocked also enters individually significantly and with the expected negative sign. The results are similar to the ones obtained for the stock of FDI. Interestingly, looking at the joint influence of infrastructure in column (10), an individually significant relationship of air-departures and international telephone circuits is found. While the former reveals a positive sign, the latter is negative. A test for the joint significance of the three infrastructure variables has a p-value of 0.001 . The variables are jointly highly significant. The individual impact of openness and natural resources remains stable. Overall, for the flow data joint significance of the infrastructure variables is found for FDI flows. An individually positive relationship exists for air-departures and FDI inflows, as documented above. 


\section{Conclusion}

The aim of this paper is to explore the link between the level of developing countries' infrastructure and their gross foreign liabilities positions. The evidence is presented in a cross-section of countries and suggests a positive relationship between the level of infrastructure and capital flows. It has been illustrated that there exists a positive correlation between international telephone circuits and countries' stock of debt. A positive impact of air-departures on the average stock and flow position of FDI is established. Additionally, there are joint effects of the infrastructure variables by analysing the FDI positions of countries.

Controlling for other determinants, countries with a diversified export structure or access to coastal areas are able to attract more FDI. Country size matters in explaining the total liability position of countries. Smaller countries hold more liabilities. Trade openness also plays an important role in explaining the stock of liabilities in the cross-section. Trading countries hold higher stocks of total liabilities and debt. However, trade openness is inversely related to the stock and flow of FDI. As one would expect, poorer countries have a higher stock of debt liabilities. Considering the geographical position of countries, an increasing distance to the equator implies lower stocks of debt and total liabilities, while it is linked to a higher stock of FDI.

Given the results established above, the level of infrastructure in countries, especially in information and transport technology, is able to explain cross country variations in FDI and debt positions of countries. Thus, it can serve as a further determinant in explaining capital flows between countries. If countries wish to increase international capital inflows, they should improve their information and transport infrastructure. The evidence established above also suggests new directions for theoretical work in modelling international capital flows by incorporating an infrastructure component into formal analyses. In future work it might be interesting to include data on new information technology, e.g. internet access, and to establish their partial correlation with international capital flows. 


\section{References}

[1] Aizenman, J. and Marion, N. (1999), Volatility and Investment: Interpreting Evidence from Developing Countries, Economica 66: 157-179.

[2] Albuquerque, R. (2000), The Composition of International Capital Flows: Risk-Sharing Through Foreign Direct Investment, mimeo, University of Rochester.

[3] Aschauer, D. A. (1989), Is Public Expenditure Productive?, J ournal of M onetary E conomics 23: $177-200$.

[4] Borensztein, E, De Gregio, J. and Lee, J.W. (1998), How does Foreign Direct Investment affect Economic Growth?, J ournal of International Economics 45: 115-135.

[5] Canning, D. (1998), A Database of World Stocks of Infrastructure, 1950-95, The World Economic Review 12: 529-547.

[6] Claessens, D., Detragiache, E., Kanbur, R. and Wickham, P. (1996), Analytical Aspects of the Debt Problems of Heavily-Indebted Poor Countries, World Bank Policy Research Working Paper 1618.

[7] Cole, H.L. and Obstfeld, M. (1991), Commodity Trade and International Risk Sharing: How much do Financial Markets matter?, J ournal of M onetary E conomics 28: 3-24.

[8] Dailami, M. and Leipziger, D. (1998), Infrastructure Project Finance and Capital Flows: A New Perspective, World Development 26: 1283-1298.

[9] Demetriades, P.O. and Mamuneas, T.P. (2000), Intertemporal Output and Employment Effects of Public Infrastructure Capital: Evidence from 12 OECD Economies, Economic J ournal 110: 687-712.

[10] Dixit, A. and Pindyck, R.S. (1994), Investment under Uncertainty, New Jersey, Princeton University Press.

[11] Easterly, W. and Rebelo, S. (1993), Fiscal Policy and Economic Growth: An Empirical Investigation, NBER Working Paper 4499.

[12] Eichengreen, B. and Fishlow, A. (1998), Contending with Capital Flows: What is Different about the 1990s?, in Capital Flows and Financial Crises, edited by Miles Kahler, Cornell, Cornell University Press. 
[13] Feldstein, M. (ed.) (1999), International Capital Flows, Chicago, University of Chicago Press.

[14] Feldstein, M. and Horioka, C. (1980), Domestic Saving and International Capital Flows, Economic J ournal 90: 314-329.

[15] Fernald, J.G. (1999), Roads to Prosperity? Assessing the link between Public Capital and Productivity, American E conomic Review 89: 619-638.

[16] Fernandez-Arias, E. (1996), The New Wave of Capital Flows: Push or Pull? J ournal of Development Economics 48: 389-418.

[17] Fernandez-Arias, E. and Hausmann, R. (2000), Is FDI a Safer Form of Financing?, InterAmerican Development Bank W orking Paper 416.

[18] Folkerts-Landau, D., Mathieson, D.J., Shinasi, G.J., et al. (1997), International Capital Markets: Developments, Prospects, and K ey Policy Issues, International Monetary Fund, Washington D.C..

[19] Frankel, J.A. and Romer, D. (1999), Does Trade Cause Growth?, American Economic Review 89: 379-399.

[20] Gallup, J.L., Sachs, J. and Mellinger, A. (1999), Geography and Economic Development, CID W orking Paper 1.

[21] Gramlich, E.M. (1994), Infrastructure Investment: A Review Essay, J ournal of Economic Literature 32: 1176-1196.

[22] Gorden, R.H. and Bovenberg, A.L. (1996), Why is Capital so Immobile Internationally?: Possible Explanations and Implications for Capital Income Taxation, American Economic Review 86: 1057-1075.

[23] Haque, U., Kumar, M.D., Mark, N. and Mathieson D. (1996), The Economic Content of Indicators of Developing Country Creditworthiness, IMF W orking Paper 96/ 619.

[24] Hausmann, R. and Fernandez-Arias, E. (2000), Foreign Direct Investment: Good Cholesterol? Inter-A merican Development B ank, W orking Paper 417.

[25] Hadi, A.S. (1992), Identifying Multiple Outliers in Multivariate Data, J ournal of the Royal Statistical Society, Series B 54: 761-771.

[26] Hadi, A.S. (1994), A Modification of a Method for the Detection of Outliers in Multivariate Samples, J ournal of the Royal Statistical Society, Series B 56: 393-396. 
[27] Henisz, W.J. (2000), The Institutional Environment for Multinational Investment, Reginald H. J ones Center Working Paper, University of Pennsylvania.

[28] Hull,L. and Tesar, L. (2000), Risk, Specialization and the Composition of International Capital Flows, mimeo, University of Michigan.

[29] International Monetary Fund (1999a), International Financial Statistics CD-Rom, Washington.

[30] International Monetary Fund (1999b), Balance of Payments Statistics CD-Rom, Washington.

[31] International Telecommunication Union (2001), W orld Telecommunication Indicators Database, Geneva.

[32] Kim, Hak-Min (1999), Globalization of International Financial Markets, Hants, Ashgate.

[33] Kraay, A., Loayza, N., Serven, L. and Ventura, J. (2000), Country Portfolios, NBE R W orking Paper 7795.

[34] Lane, P.R. (2000a), Empirical Perspectives on Long-Term External Debt, mimeo, Trinity College Dublin.

[35] Lane, P.R. (2000b), International Investment Positions: A Cross Sectional Analysis, Forthcoming in J ournal of International Money and Finance.

[36] Lane, P.R. and Milesi-Feretti, G.M. (2001a), Long Term Capital Movements, NBER Working Paper 8366 and Forthcoming in the NBER Macroeconomics Annual 2001.

[37] Lane, P.R. and Milesi-Feretti, G.M. (2001b), External Wealth, the Trade Balance and the Real Exchange Rate, prepared for the 2001 EEA/NBER International Seminar on Macroeconomics.

[38] Lane, P.R. and Milesi-Feretti, G.M. (2000), External Capital Structure: Theory and Evidence, mimeo Trinity College Dublin.

[39] Lane, P.R. and Milesi-Feretti, G.M. (1999), The External Wealth of Nations: Measures of Foreign Assets and Liabilities for Industrial and Developing Countries, IMF W orking Paper 99/115 and Forthcoming in J ournal of International Economics.

[40] Lane, P.R. and Sarisoy, S. (2000), Does Deposit Insurance stimulate Capital Inflows? E conomics Letters 69: 193-200. 
[41] Lipsey, R.E. (1999), The Role of Foreign Direct Investment in International Capital Flows, NBER Working Paper 7094.

[42] Lucas, R. (1990), Why doesn't Capital flow from Rich to Poor Countries, American Economic Review Papers and Proceedings 80: 92-96.

[43] Montiel, P. and Reinhart, C.M. (1999), The Dynamics of Capital Movements to Emerging Economies During the 1990s, in: Short-term Capital Movements and B alance of Payments Crises, edited by Griffith-Jones and Montes Oxford, Oxford University Press.

[44] Obstfeld, M. and Rogoff, K. (1996), Foundations of I nternational M acroeconomics, London, MIT Press.

[45] Pindyck, R.S. (1991), Irreversibility, Uncertainty, and Investment, J ournal of Economic Literature 29: 1110-1148.

[46] Razin, A., Sadka, E. and Yuen, C.W. (1998), A pecking order of Capital Inflows and International Tax Principles, J ournal of International Economics 44: 45-68.

[47] Sachs, J. and Warner, A. M. (1997), Natural Resource Abundance and Economic Growth, mimeo, CID and Harvard University.

[48] Stiglitz, J.E. and Weiss, A. (1981), Credit Rationing in Markets with Imperfect Information, American Economic Review 71: 393-410.

[49] Wang, J.Y. (1990), Growth, Technology Transfer and the Long-Run Theory of International Capital Movements, J ournal of International E conomics 29: 255-277.

[50] World Bank (1999a) W orld Development Indicators CD-Rom, Washington.

[51] World Bank (1999b) Global Development Finance CD-ROM, Washington.

[52] World Bank (2001) Global Development Network Growth Database, http://www.worldbank.org/research/growth/GDNdata.htm

[53] Zebregs, H. (1998), Can the Neoclassical Model Explain the Distribution of Foreign Direct Investment Across Developing Countries?, I MF Working Paper 98/139. 


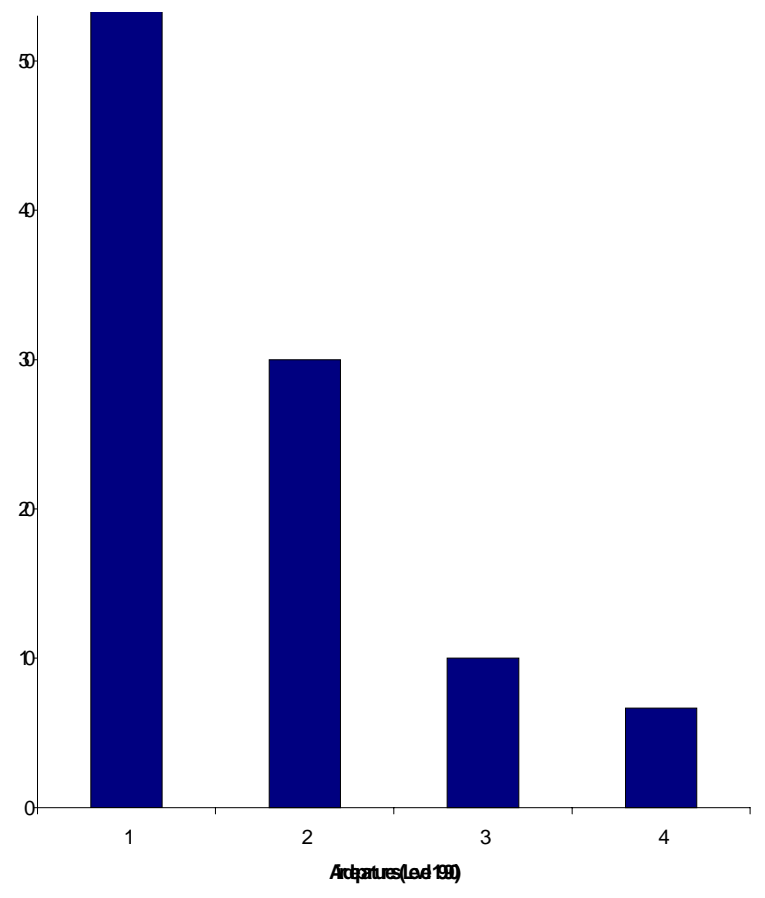

Figure 1: Histogram of Air-Departures per Capita 1990. Note: Category 1 ratio of less than 0.2 departures; 2 less than 0.4; 3 less than 0.6; 4 equal or greater than 0.6. 


$$
\text { I... }
$$




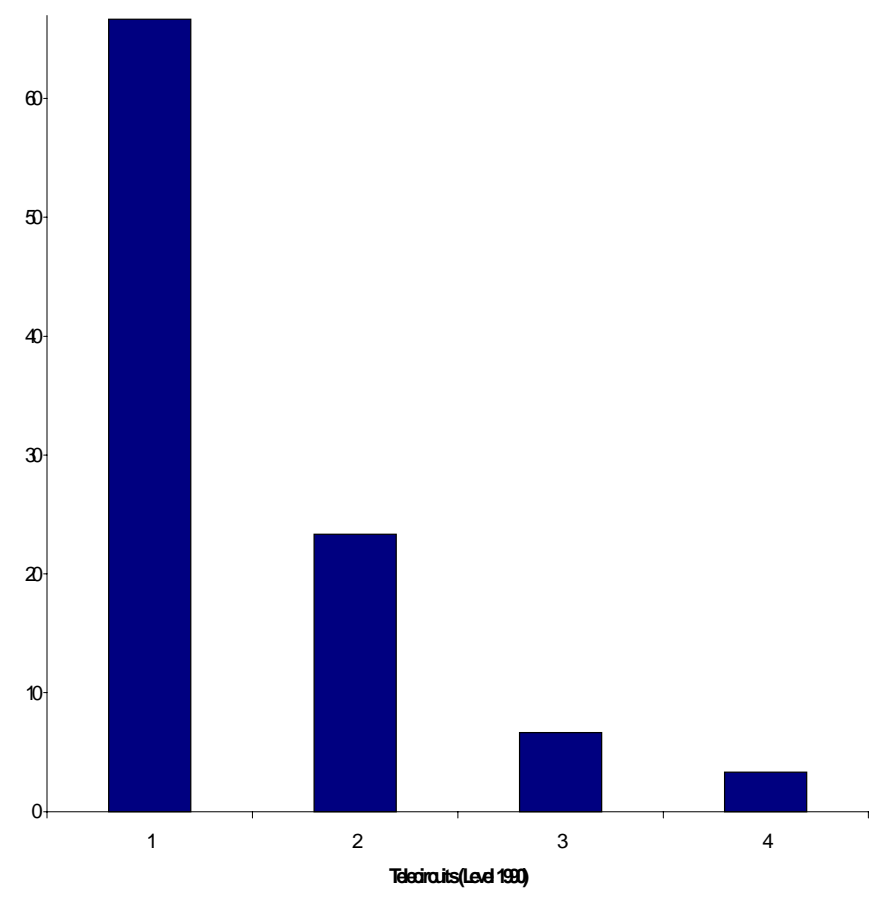

Figure 3: Histogram of International Telephone Circuits per Capita 1990. Note: Category 1 ratio of less than 0.09 telecircuits; 2 less than $0.18 ; 3$ between 0.18 and $0.36 ; 4$ greater than 0.36 . 


\begin{tabular}{|c|c|c|}
\hline Variable & Description & Sources \\
\hline $\begin{array}{c}\text { Total External Liability Stock } \\
\text { per GDP }\end{array}$ & $\begin{array}{l}\text { Total External Liability Stock = Cum. FDI } \\
\text { Liab.+ Cum. Portfolio Equity Liab. +D ebt } \\
\text { GDP in Current US } \$ \\
\text { Simple A verage for } 1990-95\end{array}$ & $\begin{array}{l}\text { Lane and M ilesi- } \\
\text { Feretti (2001) } \\
\text { World Bank (GDF } \\
\text { WDI, } 1999 \mathrm{a}, \mathrm{b}) \\
\end{array}$ \\
\hline $\begin{array}{l}\text { FDI Liability Stocks } \\
\text { per GDP }\end{array}$ & $\begin{array}{l}\text { Cum. FDI Liabilities: estimated by } \\
\text { cumulating US dollar flows. Stocks are } \\
\text { adjusted for changes in relative capital } \\
\text { goods' prices between home country and US. } \\
\text { GDP in Current US } \$ \\
\text { Simple A verage for } 1990-95\end{array}$ & $\begin{array}{l}\text { Lane and Milesi- } \\
\text { Feretti (2001) } \\
\text { World Bank (GDF } \\
\text { WDI, } 1999 \mathrm{a}, \mathrm{b}) \\
\end{array}$ \\
\hline $\begin{array}{c}\text { Portfolio Equity Liab. Stocks } \\
\text { per GDP }\end{array}$ & $\begin{array}{l}\text { Cum. Portfolio Equity Liabilities: estimated } \\
\text { by cumulating US dollar flows. Stocks } \\
\text { are adjusted to reflect year on year } \\
\text { changes in the US dollar } \\
\text { value of the domestic stock market index. } \\
\text { GDP in Current US } \$ \\
\text { Simple A verage for } 1990-95\end{array}$ & $\begin{array}{l}\text { Lane and Milesi- } \\
\text { Feretti (2001) } \\
\text { World Bank (GDF, } \\
1999 \text { a) }\end{array}$ \\
\hline Debt Stock per GDP & $\begin{array}{l}\text { Developing Countries: Stock of external } \\
\text { debt } \\
\text { GDP in Current US } \$ \\
\text { Simple A verage for } 1990-95 \\
\end{array}$ & $\begin{array}{l}\text { World Bank } \\
\text { (GDD, 2001) } \\
\text { World Bank (GDF } \\
\text { WDI, } 1999 \mathrm{a}, \mathrm{b}) \\
\end{array}$ \\
\hline $\begin{array}{c}\text { Total External Liability Flows } \\
\text { per GDP }\end{array}$ & $\begin{array}{l}\text { Total External Liability Flow = Flow } \\
\text { of Inward Direct Investment } \\
+ \text { Inward Portf. Equity +Debt } \\
\text { GDP in Current US } \$ \\
\text { Simple A verage for } 1990-95\end{array}$ & $\begin{array}{l}\text { Lane and Milesi- } \\
\text { Feretti (2001) } \\
\text { World Bank (GDF, } \\
1999 \text { a) }\end{array}$ \\
\hline $\begin{array}{l}\text { FDI Liability Flows } \\
\text { per GDP }\end{array}$ & $\begin{array}{l}\text { Flow of Inward Direct Investment } \\
\text { GDP in Current US \$ } \\
\text { Simple A verage for } 1990-95\end{array}$ & $\begin{array}{l}\text { IMF (IFS } \\
\text { BOPS, } 1999 \text { a,b) } \\
\text { World Bank } \\
\text { GDF, } 1999 \text { a) }\end{array}$ \\
\hline $\begin{array}{l}\text { Portf. Equity Liability F lows } \\
\text { per GDP }\end{array}$ & $\begin{array}{l}\text { Flow of Inward Portfolio Equity } \\
\text { GDP in Current US } \$ \\
\text { Simple A verage for 1990-95 }\end{array}$ & $\begin{array}{l}\text { IMF }(I F S \& \\
\text { BOPS, } 1999 \text { a,b) } \\
\text { World Bank (GDF } \\
\& \text { WDI, } 1999 a, b) \\
\end{array}$ \\
\hline $\begin{array}{l}\text { Debt F lows } \\
\text { per GDP }\end{array}$ & $\begin{array}{l}\text { Flow of External Debt } \\
\text { GDP in Current US } \$ \\
\text { Simple A verage for } 1990-95\end{array}$ & $\begin{array}{l}\text { IMF (BOPS, } \\
1999 \text { b) } \\
\text { World Bank (GDF } \\
\& \text { WDI, } 1999 \mathrm{a}, \mathrm{b})\end{array}$ \\
\hline
\end{tabular}

Table 1: The Dependent Variables. Note: Cum. = Cummulative; Liab. = Liability; Portf. = Portfolio. GDF = Global Development Finance; $W D I=$ World Development Indicators; GDD = Global Development Network Growth Database; IF S = International F inancial Statistics; B OBS $=$ Balance of Payments Statistics. 


\begin{tabular}{|c|c|c|}
\hline Variable & Description & Sources \\
\hline Wealth & $\begin{array}{l}\text { log( GDP per Capita in Current US \$) } \\
\text { Simple A verage for } 1990-95\end{array}$ & $\begin{array}{l}\text { World B ank (GDF } \\
\& \text { WDI, } 1999 \mathrm{a}, \mathrm{b})\end{array}$ \\
\hline Size & $\begin{array}{l}\log (\text { GDP in Current US \$) } \\
\text { Simple A verage for } 1990-95\end{array}$ & $\begin{array}{l}\text { World B ank (GDF } \\
\& \text { WDI, } 1999 \mathrm{a}, \mathrm{b})\end{array}$ \\
\hline Nat. Resources & $\begin{array}{l}\text { Mineral Fuels as a Percentage of } \\
\text { M erchandise Exports } \\
\text { Simple A verage for } 1990-95\end{array}$ & $\begin{array}{l}\text { World B ank (WDI, } \\
1999 \text { b) }\end{array}$ \\
\hline Telecircuit & $\begin{array}{l}\text { Int. Telephone Circuits / Population } \\
\text { Population in Total. Level at } \\
1990\end{array}$ & $\begin{array}{l}\text { World Telecom. } \\
\text { Indicators (ITU, } \\
\text { 2001) } \\
\text { World B ank (WDI, } \\
1999 \text { b) }\end{array}$ \\
\hline Road & $\begin{array}{l}\text { Total Lenght of Concrete or Bitumen-Surfaced } \\
\text { R oads / Square km } \\
\text { Square } \mathrm{km} \text { as of Country Size. Level } \\
\text { at } 1990\end{array}$ & $\begin{array}{l}\text { Canning (1998) } \\
\text { World Bank } \\
\text { (WDI, 1999 b) }\end{array}$ \\
\hline $\begin{array}{l}\text { A ir-Departures } \\
\text { per Population }\end{array}$ & $\begin{array}{l}\text { Aircraft departures (thousands) / Population } \\
\text { Population in Total. Level at } \\
1990\end{array}$ & $\begin{array}{l}\text { World Bank } \\
\text { (WDI, } 1999 \text { b) }\end{array}$ \\
\hline Openness & $\begin{array}{l}\text { Sum of predicted Bilateral Trade Shares } \\
\text { (taken from geographical determinants } \\
\text { of the gravity model) }\end{array}$ & $\begin{array}{l}\text { Frankel and } \\
\text { R omer (1999) }\end{array}$ \\
\hline Latitude & $\begin{array}{l}\text { Latitude of country centroid. In those countries } \\
\text { where the country's centroid fell in the } \\
\text { ocean it was moved within the } \\
\text { nearest land boundary }\end{array}$ & $\begin{array}{l}\text { Sachs and } \\
\text { Warner (1997) }\end{array}$ \\
\hline L andlocked & $\begin{array}{l}\text { Dummy which takes the value } 1 \text { if the } \\
\text { country has no access to any coastline, } \\
\text { otherwise } 0 \text {. }\end{array}$ & $\begin{array}{l}\text { Gallup, Sachs } \\
\text { and M ellinger } \\
\text { (1998) }\end{array}$ \\
\hline
\end{tabular}

Table 2: The Explanatory Variables. Note: $\mathrm{Nat} .=$ Natural; Int. = International; ITU = International Telecommunication Union. Other short cuts as explained above. 


\begin{tabular}{ccc}
\hline A sia & A frica & Latin A merica \\
\hline China & Algeria & Argentina \\
India & Egypt & B olivia \\
Indonesia & Morocco & B razil \\
J ordan & South Africa & Chile \\
Korea & Tunisia & Colombia \\
Malaysia & Zimbabwe & Costa Rica \\
Pakistan & & Ecuador \\
Philippines & & Guatemala \\
Sri Lanka & & Jamaica \\
Syria & & M exico \\
Thailand & & Paraguay \\
Turkey & & Peru \\
& & Venezuela
\end{tabular}

Table 3: Country List

\begin{tabular}{|c|c|c|c|c|}
\hline \multicolumn{5}{|l|}{ Variables } \\
\hline & M ean & StDev & Max & Min \\
\hline A ir-D eparture evel & 0.23 & 0.20 & 0.89 & 0.014 \\
\hline Road $_{\text {L evel }}$ & 0.082 & 0.114 & 0.461 & 0.002 \\
\hline Telecircuit $_{\text {Level }}$ & 0.084 & 0.086 & 0.375 & 0.002 \\
\hline $\log \left((\text { GDP / C apita })_{\text {A ver age }}\right)$ & 7.99 & 0.504 & 8.97 & 7.08 \\
\hline $\log \left((G D P)_{\text {A ver age }}\right)$ & 10.73 & 1.47 & 13.16 & 8.29 \\
\hline Openness & 14.09 & 13.017 & 68.18 & 2.30 \\
\hline Nat. Resource ${ }_{\text {Aver age }}$ & 16.23 & 24.66 & 95.93 & 0.0041 \\
\hline Latitude & 9.21 & 23.02 & 39.02 & -35.82 \\
\hline Stock Tot. Liab.A verage & 0.73 & 0.363 & 1.79 & 0.224 \\
\hline Stock FDI ${ }_{\text {Average }}$ & 0.12 & 0.096 & 0.40 & 0.005 \\
\hline Stock Port. Equity ${ }_{\text {Average }}$ & 0.012 & 0.023 & 0.098 & 0.00 \\
\hline Stock Debt ${ }_{\text {Average }}$ & 0.589 & 0.339 & 1.62 & 0.157 \\
\hline Flow Tot. Liab.Average & 0.04 & 0.037 & 0.11 & -0.028 \\
\hline Flow $\mathrm{FDI}_{\text {Average }}$ & 0.016 & 0.014 & 0.069 & 0.00013 \\
\hline Flow Port. Equity ${ }_{\text {Average }}$ & 0.0025 & 0.0035 & 0.013 & 0.00 \\
\hline Flow Debt ${ }_{\text {Average }}$ & 0.025 & 0.033 & 0.119 & -0.046 \\
\hline
\end{tabular}

Table 4: Summary Statistic 


\begin{tabular}{|c|c|c|c|c|c|c|c|c|c|c|}
\hline \multicolumn{11}{|l|}{ Explanatory Variables } \\
\hline & (1) & (2) & (3) & (4) & (5) & (6) & (7) & (8) & (9) & (10) \\
\hline Air-Departure evel & $\begin{array}{l}0.802^{* * *} \\
(2.58)\end{array}$ & - & - & $\begin{array}{l}0.469 \\
(1.36)\end{array}$ & - & - & $\begin{array}{l}0.473 \\
(1.58)\end{array}$ & - & - & $\begin{array}{l}0.243 \\
(0.57)\end{array}$ \\
\hline RoadL evel & - & $\begin{array}{l}0.422 \\
(0.45)\end{array}$ & - & - & $\begin{array}{l}0.423 \\
(0.95)\end{array}$ & - & - & $\begin{array}{l}0.409 \\
(0.80)\end{array}$ & - & $\begin{array}{l}-0.0003 \\
(0.001)\end{array}$ \\
\hline Telecircuit L evel & - & - & $\begin{array}{l}2.982^{* * *} \\
(4.70)\end{array}$ & - & - & $\begin{array}{l}1.961^{* * *} \\
(2.50)\end{array}$ & - & - & $\begin{array}{l}1.331^{* *} \\
(2.21)\end{array}$ & $\begin{array}{l}0.862 \\
(1.00)\end{array}$ \\
\hline log((GDP/Capita) A ver age) & & & & $\begin{array}{l}0.037 \\
(0.29)\end{array}$ & $\begin{array}{l}0.137^{*} \\
(1.72)\end{array}$ & $\begin{array}{l}0.020 \\
(0.32)\end{array}$ & $\begin{array}{l}-0.152 \\
(1.46)\end{array}$ & $\begin{array}{l}-0.073 \\
(0.76)\end{array}$ & $\begin{array}{l}-0.121 \\
(1.51)\end{array}$ & $\begin{array}{l}-0.149 \\
(1.39)\end{array}$ \\
\hline $\log ((G D P)$ A ver age $)$ & & & & $\begin{array}{l}-0.147^{* * *} \\
(2.91)\end{array}$ & $\begin{array}{l}-0.176^{* * *} \\
(4.15)\end{array}$ & $\begin{array}{l}-0.117^{* * *} \\
(2.72)\end{array}$ & $\begin{array}{l}-0.069 \\
(1.38)\end{array}$ & $\begin{array}{l}-0.097^{*} \\
(1.84)\end{array}$ & $\begin{array}{l}-0.065 \\
(1.54)\end{array}$ & $\begin{array}{l}-0.060 \\
(1.23)\end{array}$ \\
\hline Openness & & & & & & & $\begin{array}{l}0.015^{* * *} \\
\text { (5.16) }\end{array}$ & $\begin{array}{l}0.016^{* * *} \\
(4.18)\end{array}$ & $\begin{array}{l}0.014^{* * *} \\
(4.56)\end{array}$ & $\begin{array}{l}0.014^{* * * *} \\
(3.71)\end{array}$ \\
\hline Nat. Resource $A$ ver age & & & & & & & $\begin{array}{l}0.002 \\
(0.89)\end{array}$ & $\begin{array}{l}0.002 \\
(1.00)\end{array}$ & $\begin{array}{l}0.002 \\
(1.01)\end{array}$ & $\begin{array}{l}0.002 \\
(0.92)\end{array}$ \\
\hline Latitude & & & & & & & $\begin{array}{l}-0.002 \\
(1.03)\end{array}$ & $\begin{array}{l}-0.003^{*} \\
(1.88)\end{array}$ & $\begin{array}{l}-0.003^{* *} \\
(2.30)\end{array}$ & $\begin{array}{l}-0.003 \\
(1.38)\end{array}$ \\
\hline Landlocked $\mathrm{D}$ um. & & & & & & & $\begin{array}{l}-0.263 \\
(1.28)\end{array}$ & $\begin{array}{l}-0.334 \\
(1.49)\end{array}$ & $\begin{array}{l}-0.286 \\
(1.42)\end{array}$ & $\begin{array}{l}-0265 \\
(-1.22)\end{array}$ \\
\hline $\begin{array}{l}\mathrm{R}^{2} \\
\text { adj. } \mathrm{R}^{2} \\
\text { SE } \\
\text { Sample Size }\end{array}$ & $\begin{array}{l}0.20 \\
0.17 \\
0.33 \\
29 \\
\end{array}$ & $\begin{array}{l}0.02 \\
-0.02 \\
0.37 \\
29 \\
\end{array}$ & $\begin{array}{l}0.42 \\
0.40 \\
0.28 \\
29 \\
\end{array}$ & $\begin{array}{l}- \\
0.46 \\
0.27 \\
29 \\
\end{array}$ & $\begin{array}{l}- \\
0.43 \\
0.27 \\
29 \\
\end{array}$ & $\begin{array}{l}- \\
0.54 \\
0.24 \\
29 \\
\end{array}$ & $\begin{array}{l}- \\
0.69 \\
0.20 \\
29 \\
\end{array}$ & $\begin{array}{l}- \\
0.65 \\
0.21 \\
29 \\
\end{array}$ & $\begin{array}{l}- \\
0.69 \\
0.20 \\
29 \\
\end{array}$ & $\begin{array}{l}- \\
0.67 \\
0.21 \\
29 \\
\end{array}$ \\
\hline
\end{tabular}

Table 5: Regression Results: Stock of Total Liabilities. Note: Dependent variable: Stock of Total Liabilities. Time period 1990-95. t-Statistics in absolute values. *** Represence of significance at the $1, * *$ at the $5, *$ at the 10 percent Level. 


\begin{tabular}{|c|c|c|c|c|c|c|c|c|c|c|}
\hline \multicolumn{11}{|l|}{ Explanatory Variables } \\
\hline & (1) & (2) & (3) & (4) & (5) & (6) & (7) & (8) & (9) & (10) \\
\hline Air-Departure evel & $\begin{array}{l}0.333^{* * *} \\
(4.68)\end{array}$ & - & - & $\begin{array}{l}0.345^{\text {*** }} \\
(4.03)\end{array}$ & - & - & $\begin{array}{l}0.291^{* * *} \\
(2.84)\end{array}$ & - & - & $\begin{array}{l}0.471^{* * *} \\
(4.61)\end{array}$ \\
\hline RoadL evel & - & $\begin{array}{l}0.133 \\
(0.51)\end{array}$ & - & - & $\begin{array}{l}0.122 \\
(0.52)\end{array}$ & - & - & $\begin{array}{l}0.038 \\
(0.24)\end{array}$ & - & $\begin{array}{l}-0.226^{* *} \\
(2.35)\end{array}$ \\
\hline Telecircuit L evel & - & - & $\begin{array}{l}0.301 \\
(1.07)\end{array}$ & - & - & $\begin{array}{l}0.109 \\
(0.33)\end{array}$ & - & - & $\begin{array}{l}0.035 \\
(0.13)\end{array}$ & $\begin{array}{l}-0.387^{* * *} \\
(2.87)\end{array}$ \\
\hline $\log ($ (GDP/Capita) A ver age) & & & & $\begin{array}{l}-0.017 \\
(0.55)\end{array}$ & $\begin{array}{l}0.061 \\
(1.48)\end{array}$ & $\begin{array}{l}0.057 \\
(1.25)\end{array}$ & $\begin{array}{l}0.014 \\
(0.42)\end{array}$ & $\begin{array}{l}0.075^{*} \\
(1.85)\end{array}$ & $\begin{array}{l}0.076 \\
(1.68)\end{array}$ & $\begin{array}{l}0.001 \\
(0.03)\end{array}$ \\
\hline $\log ((G D P)$ A ver age $)$ & & & & $\begin{array}{l}-0.004 \\
(0.36)\end{array}$ & $\begin{array}{l}-0.025^{*} \\
(2.02)\end{array}$ & $\begin{array}{l}-0.022^{*} \\
(1.72)\end{array}$ & $\begin{array}{l}-0.042^{* * *} \\
(2.89)\end{array}$ & $\begin{array}{l}-0.064^{* * *} \\
(4.12)\end{array}$ & $\begin{array}{l}-0.064^{* * *} \\
(3.85)\end{array}$ & $\begin{array}{l}-0.004^{* * *} \\
(3.18)\end{array}$ \\
\hline Openness & & & & & & & $\begin{array}{l}-0.004^{* * *} \\
(4.21)\end{array}$ & $\begin{array}{l}-0.004^{* * *} \\
(3.48)\end{array}$ & $\begin{array}{l}-0.004^{* * *} \\
(3.12)\end{array}$ & $\begin{array}{l}-0.003^{* * *} \\
(3.13)\end{array}$ \\
\hline Nat. ResourceA verage & & & & & & & $\begin{array}{l}-0.001^{* *} \\
(2.05)\end{array}$ & $\begin{array}{l}-0.001^{* *} \\
(2.43)\end{array}$ & $\begin{array}{l}-0.001^{* * *} \\
(2.56)\end{array}$ & $\begin{array}{l}-0.001^{* * *} \\
(2.95)\end{array}$ \\
\hline Latitude & & & & & & & $\begin{array}{l}0.0004 \\
(0.58)\end{array}$ & $\begin{array}{l}-0.0001 \\
(0.17)\end{array}$ & $\begin{array}{l}-0.0004 \\
(0.05)\end{array}$ & $\begin{array}{l}0.001^{*} \\
(1.73)\end{array}$ \\
\hline LandlockedD um. & & & & & & & $\begin{array}{l}-0.131^{* * *} \\
(2.82)\end{array}$ & $\begin{array}{l}-0.179^{* * *} \\
(3.56)\end{array}$ & $\begin{array}{l}-0.178^{* * *} \\
(3.96)\end{array}$ & $\begin{array}{l}-0.136^{* * *} \\
(3.37)\end{array}$ \\
\hline $\begin{array}{l}\mathrm{R}^{2} \\
\text { adj. } \mathrm{R}^{2} \\
\text { SE } \\
\text { Sample Size }\end{array}$ & $\begin{array}{l}0.48 \\
0.46 \\
0.46 \\
30 \\
\end{array}$ & $\begin{array}{l}0.02 \\
-0.01 \\
0.10 \\
30\end{array}$ & $\begin{array}{l}0.08 \\
0.04 \\
0.28 \\
30 \\
\end{array}$ & $\begin{array}{l}- \\
0.43 \\
0.07 \\
30 \\
\end{array}$ & $\begin{array}{l}- \\
0.10 \\
0.09 \\
30 \\
\end{array}$ & $\begin{array}{l}- \\
0.09 \\
0.09 \\
30 \\
\end{array}$ & $\begin{array}{l}- \\
0.55 \\
0.06 \\
30 \\
\end{array}$ & $\begin{array}{l}- \\
0.29 \\
0.08 \\
30 \\
\end{array}$ & $\begin{array}{l}- \\
0.29 \\
0.08 \\
30\end{array}$ & $\begin{array}{l}- \\
0.67 \\
0.05 \\
30 \\
\end{array}$ \\
\hline
\end{tabular}

Table 6: Regression Results: Stock of FDI. Note: Dependent variable: Stock of FDI. Time period

1990-95. t-Statistics in absolute values. *** Represence of significance at the $1, * *$ at the 5, *

at the 10 percent Level. 


\begin{tabular}{|c|c|c|c|c|c|c|c|c|c|c|}
\hline \multicolumn{11}{|l|}{ Explanatory variables } \\
\hline & (1) & (2) & (3) & (4) & (5) & (6) & (7) & (8) & (9) & (10) \\
\hline Air-Departure evel & $\begin{array}{l}0.433 \\
(1.31)\end{array}$ & - & - & $\begin{array}{l}0.121 \\
(0.31)\end{array}$ & - & - & $\begin{array}{l}0.214 \\
(0.62)\end{array}$ & - & - & $\begin{array}{l}-0.145 \\
(0.32)\end{array}$ \\
\hline RoadL evel & - & $\begin{array}{l}0.262 \\
(0.39)\end{array}$ & - & - & $\begin{array}{l}0.293 \\
(1.09)\end{array}$ & - & - & $\begin{array}{l}-0.368 \\
(0.94)\end{array}$ & - & $\begin{array}{l}0.223 \\
(0.56)\end{array}$ \\
\hline Telecircuit $_{\text {L evel }}$ & - & - & $\begin{array}{l}2.350^{* * *} \\
(3.00)\end{array}$ & - & - & $\begin{array}{l}1.544 \\
(1.56)\end{array}$ & - & - & $\begin{array}{l}0.945 \\
(1.61)\end{array}$ & $\begin{array}{l}1.045 \\
(1.28)\end{array}$ \\
\hline Iog((GDP/Capita) A ver age) & & & & $\begin{array}{l}0.029 \\
(0.21)\end{array}$ & $\begin{array}{l}0.050 \\
(0.64)\end{array}$ & $\begin{array}{l}-0.036 \\
(0.39)\end{array}$ & $\begin{array}{l}-0.193^{* *} \\
(2.05)\end{array}$ & $\begin{array}{l}-0.168^{* *} \\
(2.10)\end{array}$ & $\begin{array}{l}-0.198^{* * *} \\
(2.66)\end{array}$ & $\begin{array}{l}-0.180^{*} \\
(1.89)\end{array}$ \\
\hline $\log ((G D P)$ A ver age $)$ & & & & $\begin{array}{l}-0.142^{* * *} \\
(2.52)\end{array}$ & $\begin{array}{l}-0.149^{* * *} \\
(3.47)\end{array}$ & $\begin{array}{l}-0.103^{* *} \\
(2.16)\end{array}$ & $\begin{array}{l}-0.028 \\
(0.53)\end{array}$ & $\begin{array}{l}-0.037 \\
(0.79)\end{array}$ & $\begin{array}{l}-0.015 \\
(0.36)\end{array}$ & $\begin{array}{l}-0.019 \\
(0.38)\end{array}$ \\
\hline Openness & & & & & & & $\begin{array}{l}0.018^{* * *} \\
(5.80)\end{array}$ & $\begin{array}{l}0.019^{* * * *} \\
(5.38)\end{array}$ & $\begin{array}{l}0.017^{* * *} \\
(5.38)\end{array}$ & $\begin{array}{l}0.017^{* * *} \\
(4.41)\end{array}$ \\
\hline Nat. Resource $A$ ver age & & & & & & & $\begin{array}{l}0.004^{*} \\
(1.88)\end{array}$ & $\begin{array}{l}0.004^{*} \\
(2.00)\end{array}$ & $\begin{array}{l}0.004^{* *} \\
(2.05)\end{array}$ & $\begin{array}{l}0.004^{*} \\
(1.97)\end{array}$ \\
\hline Latitude & & & & & & & $\begin{array}{l}-0.001 \\
(0.40)\end{array}$ & $\begin{array}{l}-0.003 \\
(1.53)\end{array}$ & $\begin{array}{l}-0.002^{*} \\
(1.77)\end{array}$ & $\begin{array}{l}-0.003^{*} \\
(1.77)\end{array}$ \\
\hline Landlocked D um. & & & & & & & $\begin{array}{l}-0.110 \\
(0.56)\end{array}$ & $\begin{array}{l}-0.138 \\
(0.72)\end{array}$ & $\begin{array}{l}-0.106 \\
(0.58)\end{array}$ & $\begin{array}{l}-0.120 \\
(0.56)\end{array}$ \\
\hline $\begin{array}{l}\mathrm{R}^{2} \\
\text { adj. } \mathrm{R}^{2} \\
\text { SE } \\
\text { Sample Size }\end{array}$ & $\begin{array}{l}0.07 \\
0.03 \\
0.33 \\
29 \\
\end{array}$ & $\begin{array}{l}0.01 \\
-0.03 \\
0.34 \\
29 \\
\end{array}$ & $\begin{array}{l}0.30 \\
0.28 \\
0.29 \\
29 \\
\end{array}$ & $\begin{array}{l}- \\
0.33 \\
0.27 \\
29 \\
\end{array}$ & $\begin{array}{l}- \\
0.34 \\
0.27 \\
29 \\
\end{array}$ & $\begin{array}{l}- \\
0.42 \\
0.26 \\
29 \\
\end{array}$ & $\begin{array}{l}- \\
0.66 \\
0.20 \\
29 \\
\end{array}$ & $\begin{array}{l}- \\
0.66 \\
0.19 \\
29\end{array}$ & $\begin{array}{l}- \\
0.68 \\
0.19 \\
29 \\
\end{array}$ & $\begin{array}{l}- \\
0.65 \\
0.20 \\
29 \\
\end{array}$ \\
\hline
\end{tabular}

Table 7: Regression Results: Stock of Debt. Note: Dependent variable: Stock of Debt. Time period 1990-95. t-Statistics in absolute values. *** Represence of significance at the 1, ** at the $5, *$ at the 10 percent Level. 


\begin{tabular}{|c|c|c|c|c|c|c|c|c|c|c|}
\hline \multicolumn{11}{|l|}{ Explanatory Variables } \\
\hline & (1) & (2) & (3) & (4) & (5) & (6) & (7) & (8) & (9) & (10) \\
\hline Air-Departure evel & $\begin{array}{l}0.041^{* * *} \\
(2.50)\end{array}$ & - & - & $\begin{array}{l}0.047^{\text {*** }} \\
(2.45)\end{array}$ & - & - & $\begin{array}{l}0.042^{*} \\
(1.71)\end{array}$ & - & - & $\begin{array}{l}0.079^{* * *} \\
(2.94)\end{array}$ \\
\hline RoadL evel & - & $\begin{array}{l}0.008 \\
(0.31)\end{array}$ & - & - & $\begin{array}{l}0.006 \\
(0.23)\end{array}$ & - & - & $\begin{array}{l}-0.002 \\
(0.09)\end{array}$ & - & $\begin{array}{l}-0.040^{*} \\
(1.78)\end{array}$ \\
\hline Telecircuit L evel & - & - & $\begin{array}{l}0.01 \\
(0.26)\end{array}$ & - & - & $\begin{array}{l}-0.015 \\
(0.37)\end{array}$ & - & - & $\begin{array}{l}-0.016 \\
(0.56)\end{array}$ & $\begin{array}{l}-0.085^{* *} \\
(2.42)\end{array}$ \\
\hline $\log ($ (GDP/Capita) A ver age) & & & & $\begin{array}{l}-0.004 \\
(0.64)\end{array}$ & $\begin{array}{l}0.007 \\
(1.02)\end{array}$ & $\begin{array}{l}0.008 \\
(1.05)\end{array}$ & $\begin{array}{l}0.002 \\
(0.32)\end{array}$ & $\begin{array}{l}0.011 \\
(1.52)\end{array}$ & $\begin{array}{l}0.012 \\
(1.43)\end{array}$ & $\begin{array}{l}-0.001 \\
(0.09)\end{array}$ \\
\hline $\log ((G D P)$ A ver age $)$ & & & & $\begin{array}{l}0.001 \\
(0.30)\end{array}$ & $\begin{array}{l}-0.002 \\
(1.01)\end{array}$ & $\begin{array}{l}-0.003 \\
(1.18)\end{array}$ & $\begin{array}{l}-0.004 \\
(1.22)\end{array}$ & $\begin{array}{l}-0.007^{* * *} \\
(2.63)\end{array}$ & $\begin{array}{l}-0.008^{* * *} \\
(2.49)\end{array}$ & $\begin{array}{l}-0.004 \\
(-1.24)\end{array}$ \\
\hline Openness & & & & & & & $\begin{array}{l}-0.001^{* * *} \\
(3.27)\end{array}$ & $\begin{array}{l}-0.001^{* * *} \\
(4.67)\end{array}$ & $\begin{array}{l}-0.001^{* * *} \\
(3.82)\end{array}$ & $\begin{array}{l}-0.001^{* *} \\
(2.41)\end{array}$ \\
\hline Nat. ResourceA ver age & & & & & & & $\begin{array}{l}-0.0001 \\
(1.50)\end{array}$ & $\begin{array}{l}-0.0002^{* *} \\
(2.14)\end{array}$ & $\begin{array}{l}-0.0002^{* *} \\
(2.38)\end{array}$ & $\begin{array}{l}-0.0002^{* * *} \\
(2.49)\end{array}$ \\
\hline Latitude & & & & & & & $\begin{array}{l}0.0001 \\
(0.67)\end{array}$ & $\begin{array}{l}0.0002 \\
(0.17)\end{array}$ & $\begin{array}{l}0.0001 \\
(0.13)\end{array}$ & $\begin{array}{l}0.0002 \\
(1.60)\end{array}$ \\
\hline Landlocked D um. & & & & & & & $\begin{array}{l}-0.008 \\
(0.93)\end{array}$ & $\begin{array}{l}-0.015^{*} \\
(1.95)\end{array}$ & $\begin{array}{l}-0.016^{* *} \\
(2.08)\end{array}$ & $\begin{array}{l}-0.010 \\
(1.33)\end{array}$ \\
\hline $\begin{array}{l}\mathrm{R}^{2} \\
\text { adj. } \mathrm{R}^{2} \\
\text { SE } \\
\text { Sample Size }\end{array}$ & $\begin{array}{l}0.33 \\
0.30 \\
0.01 \\
30 \\
\end{array}$ & $\begin{array}{l}0.005 \\
-0.03 \\
0.01 \\
30 \\
\end{array}$ & $\begin{array}{l}0.003 \\
-0.03 \\
0.01 \\
30 \\
\end{array}$ & $\begin{array}{l}- \\
0.26 \\
0.01 \\
30 \\
\end{array}$ & $\begin{array}{l}- \\
0.02 \\
0.01 \\
30 \\
\end{array}$ & $\begin{array}{l}- \\
0.01 \\
0.01 \\
30 \\
\end{array}$ & $\begin{array}{l}- \\
0.29 \\
0.01 \\
30 \\
\end{array}$ & $\begin{array}{l}- \\
0.04 \\
0.01 \\
30\end{array}$ & $\begin{array}{l}- \\
0.05 \\
0.01 \\
30 \\
\end{array}$ & $\begin{array}{l}- \\
0.50 \\
0.01 \\
30\end{array}$ \\
\hline
\end{tabular}

Table 8: Regression Results: Flow of FDI. Note: Dependent variable: Flow of FDI. Time period

1990-95. t-Statistics in absolute values. *** Represence of significance at the $1, * *$ at the 5, *

at the 10 percent Level. 